\title{
How Do Environmental Issues Threaten Basic Human Rights? The Case of the Chernobyl Nuclear Disaster in Ukraine
}

Emrah AKYÜZ*

\begin{abstract}
The main purpose of this article is to analyse the link between environmental issues and human rights. It investigates whether environmental dangers and degradation constitutes a violation of these rights. The concept of a right to life is central to debates concerning issues of increasing environmental hazards and degradation. Environmental hazards are at the root of human rights violations and represent a major threat to people's lives as well as to the sustenance of the next generation. The right to life can be denied by events and issues with environmental consequences, such as death caused by polluted air or acute exposure to radioactivity. To reach a conclusion the study focuses on the environmental effects of the Chernobyl nuclear disaster in 1986 on five fundamental human rights: the right to life, a safe environment, health, clean water and food. The study concludes that the direct environmental results of the Chernobyl accident has threatened fundamental human rights in the regions of Ukraine, Belarus and Russia and that a clean environment is requisite for the enjoyment of human rights.

Key Words: Human Rights, Human Rights Violation, Environmental Issues, the Chernobyl Accident.

\section{Introduction}

Over the course of the previous century, environmental issues came increasingly to the forefront of political debate, as one of the world's most pressing concerns. This was due largely to the growing environmental degradation and depletion of the planet's resources (Anderson, 2000; Lahijanian, 2012). The majority of those environmental issues, which form the subject of contemporary debate, have arisen as a direct result of human activities, e.g. industrialisation and accidents at nuclear power stations (Anderson, 2000). Power generation in particular has been viewed as one of the more harmful aspects of human activity on the biophysical environment.
\end{abstract}

\footnotetext{
* A Doctoral Researcher at the Ministry of National Education, The Republic of Turkey
} 
At present, the main environmental issues prompting concern, include environmental degradation, nuclear and radiation accidents, and air pollution (Herrera et. al., 2013: 25-28). In particular, nuclear and radiation accidents have been found to lead to increasingly significant consequences to mankind, the environment, animals, plants and the well-being of life forms across the world.

There is a growing concern that environmental dangers and the consequent degradation of the earth's resources and atmosphere are having a serious and direct impact on basic human rights (Amechi, 2009). Large proportions of the global population, have, in recent years, found their health or livelihood being directly threatened by water and air pollution (including radioactive clouds), intensive farming, overpopulation and nuclear related issues, (such as nuclear fallout and high levels of radioactive waste).

A clean, safe and sustainable environment is essential to the full enjoyment of the majority of basic human rights. In spite of the fact that balancing environmental quality with human rights is clearly a challenge, there is a pressing need to acknowledge that such a balance is crucial to ensuring both sustainable living and the protection of human rights. Additionally, it needs to be recognised that it is not only human beings who are affected, but also animals and plants, due to the fact that rapid environmental changes and degradation can cause mass extinctions, triggering large and sudden drops in the earth's biodiversity. Human beings share the planet with approximately 50 million animals and species of plants, all of which depend on a relatively stable environment (Kothari and Patel, 2006). Thus, it is important for policymakers to remember that the earth does not belong to human beings alone, but that its resources are shared with other species.

This article outlines the ways in which the Chernobyl nuclear disaster, due to its effect on the environment, can be said to have threatened basic human rights. There are three fundamental objectives: the first is to determine the concepts and backgrounds informing the characterisation of human rights. The second is to analyse the connections between human rights and environmental issues. The final objective is to specifically investigate the impact of the Chernobyl nuclear accident on the right to life, a clean environment, good health, clean water and food.

\section{The Concept of the Human Rights}

The notion of human rights rests on the understanding that there are a set of essential and inalienable and inherited fundamental rights due to all 
Sosyal Bilimler Dergisi 87

human beings, regardless of nationality, language, place of residence, gender, national or ethnic origin, colour, religion or any other status (Gafoor, 2010). These rights were first recognised internationally under the Universal Declaration of Human Rights (UDHR), and specified by the United Nations in 1948 to provide a global understanding of how to individuals should be treated (Sachs, 2004 and Clemson, 2012).

The Universal Declaration of Human Rights arose directly from the experiences of the Second World War, which had led to dramatic human rights abuses. Even though the UDHR of 1948 is a milestone document in the history of human rights, it has been criticised for recognising only the rights of the individual, rather than those of communities or of the right to a safe living environment (Al Faruque and Begum, 2004). However, it did represent the first time that it was internationally recognised that human rights are applicable to every human being, and that all human beings are considered equal.

The right to live in a healthy and ecologically sound environment was added to the list of human rights in the second half of the 20th century, and can be seen as the third generation of such rights. Many international treaties and local laws and regulations on environmental protection have been introduced as a consequence of recognition of the increasing environmental issues and their impact on human rights. All human beings have the right to the protection of nature, ecosystems, forests, flora and fauna, water and atmosphere in order to preserve the biodiversity of the ecosystems they inhabit; these are also a prerequisite of first generation rights, including the right to life and health (Boyd, 2011: 171; Brei, 2013: 394399).

\section{Linking Harm to the Environment with Threats to Human} Rights

In general, the link between environmental protection and human rights has so far been concerned with the preservation of a safe and sustainable environment to the benefit of all human beings (Cullet, 1995). In spite of separate initial stages, it has been increasingly recognised over recent decades that environment issues and human rights are inherently interlinked. The first serious recognition of environmental rights and their importance to human rights began with two landmark declarations: the 1972 Declaration on the Human Environment (Stockholm Declaration) and the 1992 Declaration on Environment and Development (Rio Declaration) (Clemson, 2012). Both these declarations were landmark achievements in world history, in that they placed emphasis on the importance of an 
economically sustainable environment to insure the achievement of basic human rights for all. All human beings and rights depend on the environment in which we live.

The concept of a right to life is central to debates concerning issues of increasing environmental hazards and degradation. Environmental hazards are at the root of human rights violations and represent a major threat to people's lives as well as to the sustenance of the next generation. This is stressed in two important international human rights declarations: the European Union Charter of Human Rights (EUCHR) and the European Convention on Human Rights (ECHR). High levels of environmental protection and the improvement of environmental quality are accepted as a pre-condition for the protection of human rights by the EUCHR and ECHR (Sadeleer, 2012). These are among the many international agreements utilising procedural human rights as a method by which to achieve better environmental protection to protect human health and dignity (Shelton, 2010). If protection cannot be provided to guarantee the safety of individuals, conflict over the environment will become a conflict over human rights. Health as a human right cannot be imagined without an ecologically safe environment, as major environmental issues (such as nuclear accidents) can lead to serious human rights abuses. Hence, the right to life, personal integrity, clean water, health, materials and the development of each human being depends on protecting the environment.

\section{The Chernobyl Disaster and Human Rights Abuses}

The Chernobyl accident occurred in 1986 at the Chernobyl Nuclear Power Plant in what is now the Ukraine. It is generally known as the largest and most serious such accident in the history of the nuclear power industry (Berger, 2010; Hasegawa, 2012). It resulted in an unprecedented release of radioactive material, with adverse consequences for human beings, the ecosystem and future generations. During the past three decades, public awareness of the environmental impact of Chernobyl on human rights has arisen as a result of the increasing number of deaths and cases of thyroid cancer that have emerged in the Ukraine, Belarus and Russia. According to the International Atomic Energy Agency's report, the consequences of the Chernobyl accident also resulted in substantial transboundary atmospheric transfer and the subsequent pollution of many Western countries (IAEA, 2006). Thus, the accident was not just a problem with a regional impact, but one with global consequences.

The relationship between environmental and human rights was demonstrated by the contamination of region. Increasing numbers of the 
Sosyal Bilimler Dergisi 89

population have suffered the consequences of an unbalanced and unsafe ecosystem over the last three decades, with their basic human rights being threatened by the presence of radioactive material in the environment. According the recommendations above, fundamental human rights are impossible to benefit in the absence of an ecologically clean environment.

\section{a. The Right to Life and Environment}

The Chernobyl nuclear plant accident was responsible for causing deaths both directly and indirectly. Unfortunately, there is little reliable information concerning the numbers affected by the accident, and all figures are fiercely debated. A United Nation's report (published in 2005 by the Chernobyl Forum) estimates that the accident will eventually cause approximately 4,000 deaths, the majority of these manifesting as cancer related illnesses (The Chernobyl Forum, 2005). In contrast, 'The Chernobyl Catastrophe Consequences on Human Health' (published in 2006 by Greenpeace) estimates 200,000 radiation-related deaths occurred between 1990 and 2000 in Russia, the Ukraine and Belarus (Greenpeace, 2006). According to 'The Other Report on Chernobyl or Torch', there have been between 30,000 and 60,000 deaths, most of these cancer-related (Fairlie and Sumner, 2006). It is certain that thousands of deaths have occurred during recent decades in the radioactive zone as a direct result of the accident.

It has been accepted by the World Health organisation that (according to varying reports) 203 power plant employees and fire fighters were hospitalised immediately, of whom 30 died within a few days (World Health Organisation, 2006). Chernobyl cannot be categorised as an environmental disaster, as occurred as the direct result of an unwanted accident. This kind of accident can happen at any time, but the long-term effects of uncontrolled radioactivity (including air and water pollution, increasing numbers of cancer cases and related deaths, radioactive food and water) have threatened basic human rights, in particular the right to life and health.

The right to life is clearly the most fundamental of human rights, as stated by Przetacznick: "the enjoyment of the right to life is pre-requisite of the enjoyment of all other human rights (Przetacznick, 1976). Every human being has an inherent right to life, and this right is one that must be protected from abuses by the State in accordance with laws and international agreements. An example of such an agreement is the Universal Declaration of Human Rights, Article 3 of which states that: "Everyone has the right to life, liberty and security of person" (Amnesty International, 2013). It raises the following question: How can the right to life be protected 
in a radioactive area? The answer is in protection of environment. Radioactive environmental contamination is deadly to human beings, and the right to life is clearly meaningless in the absence of a clean and safe ecosystem. For the safeguarding of all human rights (including civil, cultural and economic), a clean and safe environment is requisite, and therefore the environment needs to be protected. Thus, environmental issues and the consequences of human activity can put human rights at risk, and the minimum requirement (a clean environment), was put at risk by the accident. It is impossible to establish if a nuclear accident in itself is a human rights violation, but the Chernobyl disaster as an environmental issue has threatened the right to life due to the amount of radioactive materials in the region. The 1972 Stockholm Declaration underlines protection of the earth from non-renewable energy like nuclear energy. It is stated that: The nonrenewable resources of the earth must be employed in such a way as to guard against the danger of their future exhaustion and to ensure that benefits from such employment are shared by all mankind (Principle 5)

As a result of raising environmental issues and their effect on the enjoyment of human rights, a human rights approach to environmental concerns was introduced in the 1970s. The 1972 declaration of the United Nations Conference on the Human Environment in 1972 is a milestone in terms of the protection of nature. This declaration inspires and guides the peoples of the world in the preservation and enhancement of the human environment. Principle 1 of the 1972 Stockholm Declaration established a foundation for linking human rights and environmental protection, declaring that:

--Man has the fundamental right to freedom, equality and adequate conditions of life, in an environment of a quality that permits a life of dignity and well-being, and he bears a solemn responsibility to protect and improve the environment for present and future generations. (United Nation Environment Programme, 2013)

Similarly, the Rio Declaration on the Environment and Development defines the rights of the population and the responsibilities of human beings to safeguard their environment. Despite the fact that the 1992 Rio Declaration does not grant the right to a clean environment directly, it places emphasis on the importance of nature. It states that: Human beings are in the centre for sustainable development. They are entitled to a healthy life in harmony with nature (United Nations, 1992).

As can be seen in both the Stockholm and Rio Declarations, an unsafe and unhealthy environment and the enjoyment of human rights are 
Sosyal Bilimler Dergisi 91

not mutually exclusive, thus a clean environment and the promotion of human rights are increasingly being viewed as intertwined.

At the international level, there are two more crucial international human rights instruments that have been introduced, and which place emphasis on the importance of a safe environment. Article 24 of the 1981 African Charter on Human Rights and Peoples' Rights states that: "All peoples shall have the right to a general satisfactory environment favourable to their development" (University of Minnesota, 1986). Similarly, the 1988 San Salvador Protocol on Economic, Social and Cultural Rights to the 1969 American Convention on Human Rights (article 11) states that: "Everyone shall have the right to live in a healthy environment and to have access to basic public services" (Inter-American Commission on Human Rights, 2013). Human beings are unable to continue living at a level that is commensurate with the minimum standards of human dignity without access to a clean, safe and healthy environment, and under unhealthy environmental conditions (such as a radioactive region) human rights remain at risk.

\section{b. The Right to Health}

The World Health Organisation defines the right to health as a fundamental right of every human being and our understanding of a life lived in dignity (WHO, 2013). Thyroid cancer, caused by radioactive iodine, was one of the main manifestations of the health impacts of the Chernobyl accident, particularly amongst young people. The reactor fire released huge amounts of uncontrolled radioactive substances into the air. Children are generally more at risk of thyroid cancer more than adults, as the radioactive material will be more concentrated in the thyroid of children than adults (Rettner, 2011). Statistical evidence points to the incidence of thyroid cancer among young children in the fall out area as having increased rapidly since the Chernobyl disaster (Yablokov, 2012). In the Convention on the Rights of the Child, (a human rights treaty setting out the rights of children) it states that: States Parties recognise the right of the child to enjoyment of the highest attainable standard of health and facilities for treatment of illness and rehabilitation of health. (Article 24) (UNHR, 1989). Additionally, the International Bill of Human Rights (established by the United Nations in 1948) proclaims that "everyone has the right to life, liberty and security of person" (Article 1)

As a result of the radiation exposure to the thyroid gland, thyroid cancer has also been rising rapidly among older people, and the health of those surviving Chernobyl victims is deteriorating. It is estimated that millions were affected by radiation in the Ukraine, Russia and Belarus (IAEA, 2005). Therefore, around five million people today live under the 
threat of cancer or serious disease in the radioactive area. In addition to this, while thyroid cancer is the most demonstrable health impact of the Chernobyl accident, mental health and psychological effects have increasingly emerged as a problem, due to the extensive relocation of people and the loss of economic stability following the disaster (World Health Organisation, 2006).

Security and the right to health are guaranteed in all international human rights declarations. The 1972 Declaration of the Human Environment states that:

Both aspects of man's environment, the natural and the manmade, are essential to his well-being and to the enjoyment of basic human rights the right to life itself... Man has the fundamental right to freedom, equality and adequate conditions of life, in an environment of a quality that permits a life of dignity and well-being, and he bears a solemn responsibility to protect and improve the environment for present and future generations (Principle 1)

This declaration demonstrates that a sustainable environment is significant to insuring human dignity and wellbeing. They regard the protection of the environment as a prerequisite for the right to life and health. It is true that the lack of a safe environment can create a serious risk with major implications for the health of human beings. Those living in a radioactive area often have a significantly higher incidence of a lack of good health than those living in a safe area.

\section{c. The Right to Food and Water}

Kofi Annan states that: "Access to safe water is a fundamental human need and, therefore, a basic human right. Contaminated water jeopardises both the physical and social health of all people. It is an affront to human dignity." (Kofi Annan, United Nations Secretary General, 2013). Human beings cannot exist in the absence of access to safe food and water. This is a fundamental human right, as derived from the International Covenant on Economic, Social and Cultural Rights (CESCR), adopted by the United Nations General Assembly on 16 December 1966, and in force since 3 January 1976. It declares that: The States Party to the present Covenant recognise the right of everyone to an adequate standard of living for himself and his family, including adequate food (United Nations Human Rights, 2012)

It is the fact that the earth supports human life by providing what is needed for survival. The basic elements for human beings include air, water, soil, animals and plants. Clean and safe food is a fundamental right of all 
Sosyal Bilimler Dergisi 93

human beings, as is the right to clean drinking water. The second principle of the Stockholm Declaration proclaims that:

The natural resources of the earth, including the air, water, land, flora and fauna and especially representative samples of natural ecosystems, must be safeguarded for the benefit of present and future generations through careful planning or management, as appropriate (Principle 2)

In an area contaminated with radioactivity there is no access to safe food and water and this therefore leads to a range of human rights violation within that location. The Chernobyl disaster is a dramatic example of how environmental issues threaten the right to clean water and food.

Approximately 100,000 square miles of land in the Ukraine, Russia and Belarus were contaminated with radio nucleotides in 1986 (Ogrodnik, et al., 2013). In the years prior to the Chernobyl accident, the area was surrounded by forest, bodies of water and urban centres. About $40 \%$ of the land was used for agricultural purposes. Following the disaster, drinking water supplies and agricultural produce in the area were subject to the highest levels of radiation (Barbalace, 1999), and since that time access to drinking water and food has become an increasingly serious issue for those who have continued living in the region.

\section{Conclusion}

This paper has focused on the relationship between human rights violations and environmental issues, as important concerns in an increasingly populated planet with limited resources. Specifically, it has analysed the environmental effect of the Chernobyl nuclear disaster on the right to life, a healthy environment, clean water and food; all of which are accepted as fundamental human rights by both the Universal Declaration of Human Rights (UDHR) and the 1981 African Charter on Human Rights and People Rights.

Firstly, it has been reported above, that the accident caused the largest uncontrolled radioactive release into the environment ever experienced. This led to serious environmental consequences, in particular air pollution and water contamination. The right to life demands a clean and safe environment, and this contamination led to thousands of cancer deaths in Russia, Ukraine and Belarus between 1990 and 2000. Furthermore, an increased number of cancer deaths can be expected during the lifetimes of all those exposed to radiation released during the Chernobyl accident. The accident had deleterious health consequences for the majority of the population in Ukraine. Moreover, as a result of the radioactivity levels, 
thyroid cancer has become one of the main health impacts generated by the Chernobyl accident to affect inhabitants, in particular younger people. The right to heath is protected by a clean and safe environment. In the contaminated area around Chernobyl, human health has been threatened by this radioactive release. The last environmental effect of the Chernobyl disaster relates to the right to clean water and food. These are two indispensable needs for the protection of the rights of human beings to feed themselves in dignity. The accident raised concerns about the safety of water and food in the radioactive area; the water near the nuclear reactor cooling pond was particularly contaminated.

As a result, the environmental effect of the Chernobyl nuclear accident can be said to have caused serious human rights violations, mainly in Ukraine, Russia and Belarus. The populations in the radioactive zone have been suffering for a quarter of a century from the continuous threat to life, environment, health, clean water and food. This situation is clearly a violation of their Fundamental Human Rights. The nuclear accident has converted habitable areas into uninhabitable ones, and human lives have been lost; furthermore, for some the effects are still being felt today. It is still the case that, the majority of the 'contaminated' territories in the region remain unsafe for both human settlement and economic activity.

\section{References}

AL FARUQUE, A. and BEGUM, N. (2004). Conceptualising Indigenous Peoples Rights: An Emerging New Category of Third-Generation Rights, Asia-Pacific Journal on Human Rights \& the Law. 2004,. 5 (2), 129. 29.

AMNESTY INTERNATIONAL (2013). Article Three of the Universal Declaration. Available online at: $<$ http://www.amnesty.org/en/universal-declaration-human-rightsanniversary/article-three> [Accessed: 1 April 2014]

ANDERSSON, Lynne M. (2012). Individual Environmental Initiative: Championing Natural Environmental Issues in US Business Organizations. Academy of Management Journal, 43 (4), 548-570.

AMECHI, Emeka Polycarp (2009). Enhancing Environmental Protection and Socio-Economic Development in Africa: A Fresh Look at the Right to a General Satisfactory Environment under the African Charter on Human and Peoples' Rights, Environment and Development Journal, 5 (1), 60-71.

BERGER, Eva M. (2010). The Chernobyl Disaster, Concern about the Environment, and Life Satisfaction. Kyklos, 63 (1), 1-8. 
Sosyal Bilimler Dergisi 95

BOYD, David R. (2011). The Implicit Constitutional Right to Live in a Healthy Environment. Review of European Community \& International Environmental Law, 20 (2), 171-179.

BARBALACE, R. C. (1999). Chernobyl Disaster's Agricultural and Environmental Impact. Advance Online Publication. http://environmentalchemistry.com/yogi/hazmat/articles/chernobyl3 .html

CHERNOBYL'S CANCER WORLD RECORD. (2013, 15 January). BBC, 1.

CULLET, P. (1995). Definition of an Environmental Right in a Human Rights Context. 13 Netherlands Quarterly of Human Rights, 25-40.

CLEMSON, M. (2012). Human Rights and the Environment: Access to Energy. New Zealand Journal of Environmental Law, 16 (2), 39-81.

EDITORIAL: Chernobyl Forum, 2003-2005. (2005). International Atomic Energy Agency, 1-2.

EDITORIAL: Additional Protocol to the American Convention on Human Rights in the Area of Economic, Social and Cultural Rights "Protocol of San Salvador". (1988). Inter-American Commission on Human Rights.

FAIRLIE, L. and SUMNER, D. (2006). The Other Report on Chernobyl. Berlin, Brussels, Kiev: TORCH.

FARYADI, Sh.; TAHERI, Sh. (2009). Interconnections of Urban Green Spaces and Environmental Quality of Tehran. International Journal of Environmental Research, 3 (2), 199-208.

GAFOOR, K.A. A. (2010). Human Rights: Rights to Life. Rajagiri Journal of Social Development, 1 (2),

HERRERA, I.; DE RUYCK, J.; OCANA, VS; RUBIO, M.; MARTINEZ, R.; NUNEZ, V. (2013). Environmental Impact of Decentralized Power Generation in Santa Clara City, Cuba: An Integrated Assessment Based on Technological and Human Health Risk Indicators. Applied Energy, 109, 24-35.

INTERNATIONAL ATOMIC ENERGY AGENCY (2006). Environmental Consequences of the Chernobyl Accident and Their Remediation: Twenty Years of Experience (Report 8). Vienna: Radiological Assessment Reports.

KOTHARI, A. and PATEL, A. (2006). Environment and Human Rights. India: National Human Rights Commission.

GREENPEACE (2006). The Chernobyl Catastrophe Consequences on Human Health (Report 1). Amsterdam.

OGRODNIK, A., HUDON, T.W., NADKARNI, P.M. and CHANDAWARKAR, R.Y. (2013). Radiation Exposure and Breast 
Cancer: Lessons from Chernobyl. Connecticut Medicine, 77 (4), 227234.

SHELTON, D. (2002). Human Rights, Health \& Environmental Protection: Linkages in Law \& Practice. Health and Human Rights Working Paper Series No 1.

SADELEER, N. D. (2012). Enforcing EUCHR Principles and Fundamental Rights in Environmental Cases. Nordic Journal of International Law, 81 (1), 39-74.

SACHS, W. (2004). Environment and Human Rights. Wuppertal Institute for Climate, Environment, Energy.

UNITED NATIONS OFFICE OF THE HIGH COMMISSIONER FOR HUMAN RIGHTS (2006). Frequently Asked Question on a Human Rights-Based Approach to Development Cooperation. Available online

at:

<p://www.ohchr.org/Documents/Publications/FAQen.pdf.>

[Accessed: 1 April 2014]

RETTNER, R. (March 15 2011). How Does Nuclear Radiation Harm the Body?. MyHealthNewsDaily.

THE CHERNOBYL FORM (2005). Chernobyl's Legacy: Health, Environmental and Socio-Economic Impacts and Recommendations to the Governments of Belarus, the Russian Federation and Ukraine (Report No. 2). Belarus, Ukraine and the Russian Federation: The Chernobyl Forum: 20032005.

YABLOKOV, A. (2012). Debate on the Chernobyl Disaster: Response to Dr. Sergei V. Jargin. International Journal of Health Services, 42 (1), 35-44.

WORLD HEALTH ORGANIZATION (2003). The Right to Water. Health and human rights publication series; no. 3 .

WORLD HEALTH ORGANIZATION (2006). Health Effects of the Chernobyl Accident and Special Health Care Programmes (Report 1). Geneva: UN Chernobyl Forum Expert Group "Health.

http://www.ohchr.org/en/professionalinterest/pages/crc.aspx

http://www.ohchr.org/EN/ProfessionalInterest/Pages/CESCR.aspx http://www.un.org/en/documents/udhr/

http://www.unep.org/Documents.Multilingual/Default.asp?documentid=97 \&articleid $=1503$

http://www.un.org/documents/ga/conf151/aconf15126-1annex1.htm http://www1.umn.edu/humanrts/instree/z1afchar.htm

http://www.unep.org/Documents.Multilingual/Default.asp?DocumentID=97 \&ArticleID $=1503$ 
Sosyal Bilimler Dergisi 97

http://www.who.int/ionizing_radiation/chernobyl/backgrounder/en/index.h tml

http://en.wikipedia.org/wiki/Effects_of_the_Chernobyl_disaster

http://www.who.int/ionizing_radiation/chernobyl/backgrounder/en/index.h tml

http://www.livescience.com/13250-radiation-health-effects-japan-nuclearreactor-cancer.html. 
E. AKYÜZ | 98 